\title{
Mapping burn severity in a disease-impacted forest landscape using Landsat and MASTER imagery
}

\author{
Gang Chen ${ }^{\mathrm{a}, *}$, Margaret R. Metz ${ }^{\mathrm{b}, \mathrm{c}}$, David M. Rizzo ${ }^{\mathrm{c}}$, Ross K. Meentemeyer ${ }^{\mathrm{d}, \mathrm{e}}$ \\ a Department of Geography and Earth Sciences, University of North Carolina at Charlotte, 9201 University City Blvd, Charlotte, NC 28223, USA \\ ${ }^{\mathrm{b}}$ Department of Biology, Lewis E' Clark College, 0615 S.W. Palatine Hill Road, MSC 53, Portland, OR 97219, USA \\ ' Department of Plant Pathology, University of California, 1 Shields Ave, Davis, CA 95616, USA \\ d Center for Geospatial Analytics, North Carolina State University, 3120 Jordan Hall, Raleigh, NC 27695, USA \\ e Department of Forestry and Environmental Resources, North Carolina State University, 3120 Jordan Hall, Raleigh, NC 27695, USA
}

\section{A R T I C L E I N F O}

Article history:

Received 20 December 2014

Accepted 7 April 2015

\section{Keywords:}

Burn severity

Forest fire

Disease invasion

MASTER

Landsat

Sudden oak death

Interacting disturbances

\begin{abstract}
A B S T R A C T
Global environmental change has increased forest vulnerability to the occurrence of interacting disturbances, including wildfires and invasive diseases. Mapping post-fire burn severity in a disease-affected forest often faces challenges because burned and infested trees may exhibit a high similarity in spectral reflectance. In this study, we combined (pre- and post-fire) Landsat imagery and (post-fire) high-spectral resolution airborne MASTER data [MODIS (moderate resolution imaging spectroradiometer)/ASTER (advanced spaceborne thermal emission and reflection radiometer)] to map burn severity in a California coastal forest environment, where a non-native forest disease sudden oak death (SOD) was causing substantial tree mortality. Results showed that the use of Landsat plus MASTER bundle performed better than using the individual sensors in most of the evaluated forest strata from ground to canopy layers (i.e., substrate, shrubs, intermediate-sized trees, dominant trees and average), with the best model performance achieved at the dominant tree layer. The mid to thermal infrared spectral bands $(3.0-12.5 \mu \mathrm{m})$ from MASTER were found to augment Landsat's visible to shortwave infrared bands in burn severity assessment. We also found that infested and uninfested forests similarly experienced moderate to high degrees of burns where CBI (composite burn index) values were higher than 1 . However, differences occurred in the regions with low burn severity (CBI values lower than 1 ), where uninfested stands revealed a much lower burn effect than that in infested stands, possibly due to their higher resilience to small fire disturbances as a result of higher leaf water content.
\end{abstract}

Published by Elsevier B.V.

\section{Introduction}

Forests play a key role as global terrestrial carbon sinks responsible for an annual uptake of over one quarter of the anthropogenic carbon dioxide $\left(\mathrm{CO}_{2}\right)$ from the atmosphere (Pan et al., 2012). Compared to the net carbon sequestration through tree growth, carbon loss may be occurring at a faster pace through natural disturbances including wildfire (Kurz et al., 2008a; Asner, 2013). Recently, increased fire activities have been reported in major forest biomes, such as Brazilian Amazon, Canadian boreal and western USA (Carcaillet et al., 2001; Westerling et al., 2006; Morton et al., 2013). In the short term, forest fires directly transform living and dead organic matter at or above the soil surface to charred and blackened residues (Kokaly et al., 2007), which in the long term

\footnotetext{
* Corresponding author. Tel.: +1 704687 5947; fax: +1 7046875966

E-mail address: gang.chen@uncc.edu (G. Chen).
}

may affect the structure and function of the ecosystem, and influence the spatial patterns of ecological succession (Turner et al., 1998; Metz et al., 2012, 2013). Hence, it is critical to understand the combustion degree of organic matters and the impact of heat on soil chemical properties in forests immediately following fire events, where the practice is typically referred to as burn severity assessment (Neary et al., 2005; Key and Benson, 2006; Lentile et al., 2006; Kokaly et al., 2007; Keeley, 2009). Over the last three decades, remote sensing has proven effective in assessing the impacts of fire on forest ecosystems at local, regional and continental scales (Hall et al., 1980; Milne, 1986; Jakubauskas et al., 1990; White et al., 1996; Hudak and Brockett, 2004; Lentile et al., 2006; Veraverbeke et al., 2012). While the detection of fire extents ("where") using remote sensing is relatively well established, recent research efforts have advanced the measurement of "how severely" wildfires change post-disturbance forest landscapes (i.e., burn severity) by capitalizing on the variation in spectral reflectance from burned vegetation and soil shortly after the fire events (Miller and Yool, 2002; Epting 
et al., 2005; Roy et al., 2006; Lentile et al., 2006; Miller and Thode, 2007; Harris et al., 2011; Quintano et al., 2013). Here, we adopted the definition of burn severity as "the degree to which an ecosystem has changed owing to the fire" (Lentile et al., 2006). Statistical regression and image classification are typical approaches used to link spectral reflectance from a burned forest with a field-measured burn severity index, such as composite burn index (CBI) ranging from zero to three or low to high (Key and Benson, 2006; Hultquist et al., 2014).

Although there has been a growing body of literature on the application of remote sensing to assess burn severity across a diversity of environments [see reviews by Lentile et al. (2006) and Keeley (2009)], few studies have discussed the uncertainty in mapping burn severity in a forest that is also subject to severe disturbances caused by invasive pests or pathogens. While increased fire events have been observed mainly due to the impact of warming fostered drought, the intensity and frequency of insect invasions and disease epidemics are likely to be accelerated resulting from global trade (Bergot et al., 2004; Wulder et al., 2006; Kurz et al., 2008b; Lamsal et al., 2011; Olsson et al., 2012). Studies have found that it is becoming more frequent that wildfire affects a forest invaded by an exotic insect or disease (Jenkins et al., 2008; Metz et al., 2013). Since the outbreaks of insect or disease could dramatically increase host fuel abundance and exhibit different patterns (due to patchy dispersal by the pest) (Meentemeyer et al., 2012), accurate assessment of forest burn severity requires a comprehensive investigation of how non-native species, including infectious disease, affect fire behavior. However, relatively little consideration has been given to the role that invasive pests or pathogens play in shaping spatial heterogeneities of burn severity.

To date, remotely sensed data used in the majority of burn severity studies have been from traditional sensors, such as Landsat and SPOT (Satellite Pour l'Observation de la Terre) (e.g., Roy et al., 2006; Fox et al., 2008). Although promising results were reported with these broadband sensors using the VNIR-SWIR (visible to shortwave infrared, $0.4-3.0 \mu \mathrm{m}$ ) spectral region, it remains unclear whether such data sets can provide satisfactory performance mapping burn severity in diseased forests, because post-fire spectral reflectance is complicated by both the degree of burn severity and disease-caused tree mortality. The disturbances of fire and forest disease may change spectral reflectance in similar ways. Recently, researchers found that sensors with an ability to acquire imagery of higher spectral resolution and broader spectral range may provide greater insights into the impact of fires on forests (Wagtendonk et al., 2004Wagtendonk et al., 2004 Kokaly et al., 2007; Veraverbeke et al., 2012). MASTER [MODIS (moderate resolution imaging spectroradiometer)/ASTER (advanced spaceborne thermal emission and reflection radiometer)] airborne simulator is an example of a sensor capable of collecting 50-band imagery covering both the VNIR-SWIR and MIR-TIR (mid to thermal infrared, 3.0-12.5 $\mu \mathrm{m}$ ) spectral ranges. Hence, MASTER may have the potential to recognize disturbance related subtle variations in spectral reflectance, and augment burn severity assessments from broadband Landsat data in diseased forests.

Capitalizing on the emerging infectious disease sudden oak death (SOD) as case study of forest health decline prior to fire, we ask two questions that address the potential for combing MASTER airborne and Landsat TM data to assess the impact of a pre-fire biotic disturbance on forest burn severity: (i) what is the performance of combining MASTER and Landsat TM data in burn severity assessments compared to using data from individual sensors? (ii) Does SOD tree mortality influence burn severity measured using $\mathrm{CBI}$ in various forest strata from ground to canopy layers (i.e., substrate, herbs, shrubs, intermediate trees, dominant trees and the average)?

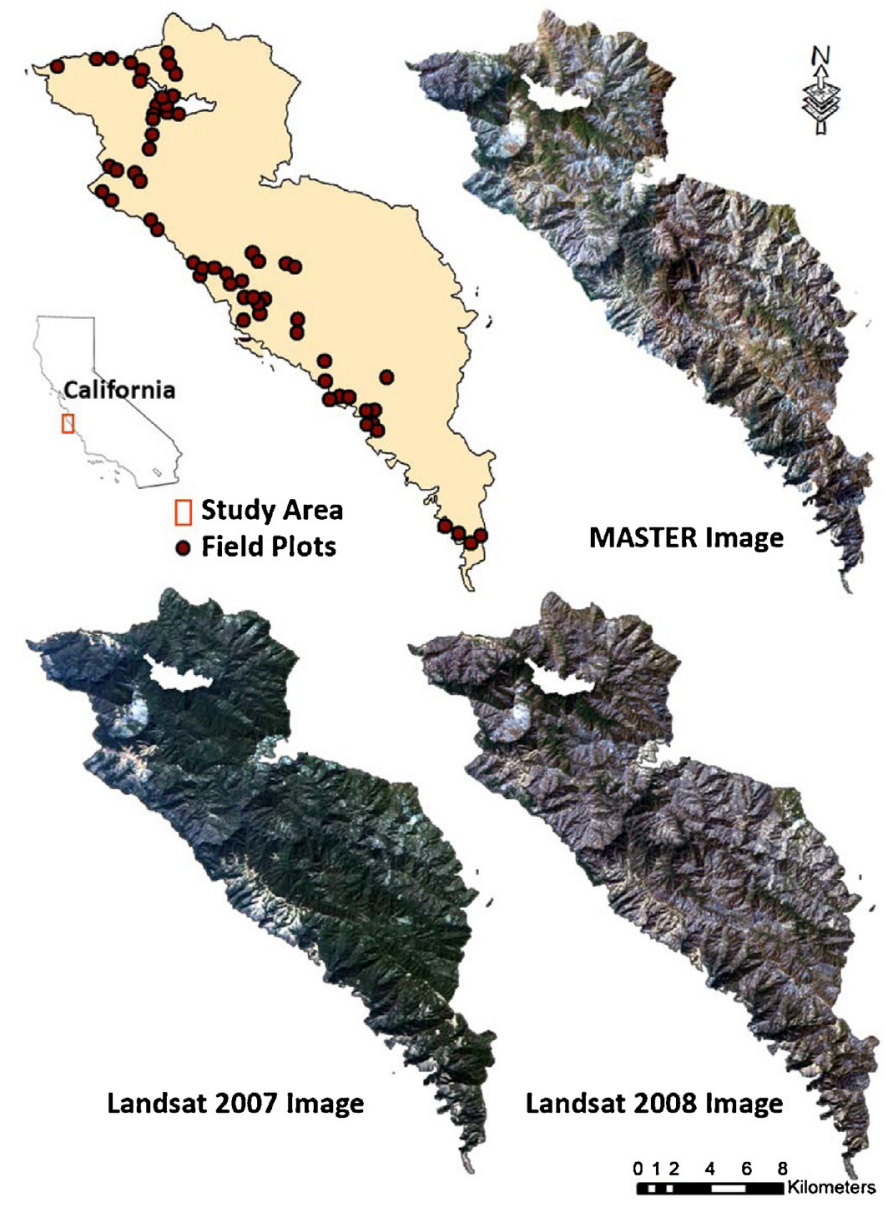

Fig. 1. Study area located in the Big Sur ecoregion on the western flank of the Santa Lucia Mountains in California. The MASTER image is from a color composite using bands 5 (red), 3 (green) and 1 (blue). The 2007 and 2008 Landsat TM images are from a color composite using bands 3 (red), 2 (green) and 1 (blue). (For interpretation of the references to color in this figure legend, the reader is referred to the web version of this article.)

\section{Methods}

\subsection{Study area}

Our study site (centered at: $36^{\circ} 16^{\prime} \mathrm{N}, 121^{\circ} 44^{\prime} \mathrm{W}$ ) was located in the Big Sur ecoregion on the western flank of the Santa Lucia Mountains in California, covering an area of 28,383 ha (Fig. 1). The area featured Mediterranean-type climate and a rugged landscape dissected by steep slopes and drainages with elevations ranging from sea level to $1571 \mathrm{~m}$ within $5 \mathrm{~km}$ of the coast (Meentemeyer et al., 2008). Mixed coniferous forests, composed primarily of ponderosa pine (Pinus ponderosa), sugar pine (Pinus lambertiana), Jeffrey pine (Pinus jeffreyii), coulter pine (Pinus coulteri), and Santa Lucia fir (Abies bracteata), were located on upper elevation slopes and rocky ridges; while chaparral shrubland and annual grassland often dominated dry south-facing slopes and ridges at mid elevations (Davis et al., 2010). In addition, mixed oak woodland consisting of coast live oak, Shreve's oak, bay laurel (Umbellularia californica), and madrone (Arbutus menziesii) occurred on moister slopes, giving way to riparian corridors of redwood-tanoak forest at lower elevations (Davis et al., 2010). Since the mid-1990s, an invasive non-native pathogen Phytophthora ramorum - causing the disease sudden oak death (SOD) - has led to substantial mortality in two plant communities - mixed oak woodland and redwood-tanoak forests (Rizzo et al., 2005). Despite the name 'sudden' oak death, the disease is a multi-year process that typically begins with suitable temperature 
Table 1

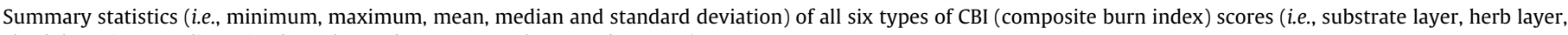
shrub layer intermediate-sized tree layer, dominant tree layer, and average).

\begin{tabular}{|c|c|c|c|c|c|}
\hline Type of CBI score & Minimum & Maximum & Mean & Median & Standard deviation \\
\hline Substrate layer & 0.15 & 2.66 & 1.79 & 1.82 & 0.48 \\
\hline Herb layer & 0.50 & 3.00 & 2.71 & 3.00 & 0.53 \\
\hline Shrub layer & 0.00 & 3.00 & 2.40 & 2.50 & 0.45 \\
\hline Intermediate-sized tree layer & 0.38 & 3.00 & 1.53 & 1.50 & 0.59 \\
\hline Dominant tree layer & 0.38 & 3.00 & 1.31 & 1.25 & 0.67 \\
\hline Average & 0.58 & 2.93 & 1.96 & 1.96 & 0.40 \\
\hline
\end{tabular}
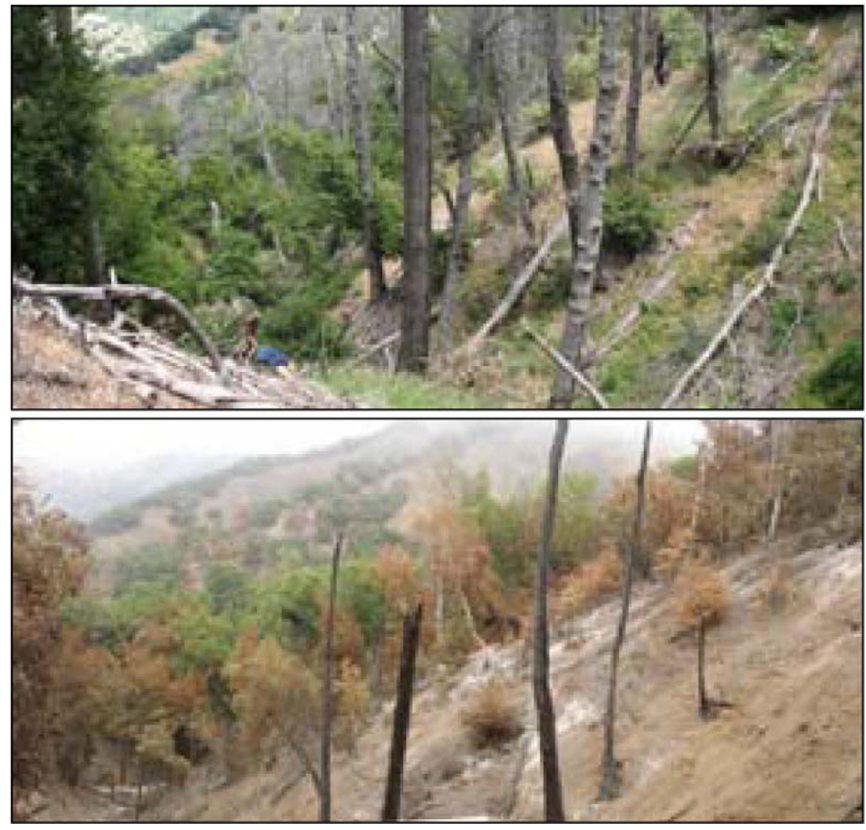

Fig. 2. An area affected by pre-fire SOD, with many large dead tanoaks and piles of tanoak logs (top image), and severely damaged by the 2008 Basin Complex Fire (bottom image).

and rainfall conditions for pathogen sporulation followed by development of stem cankers in susceptible hosts tanoak and some oaks, which may girdle a tree over several years or make the tree more susceptible to attack by other pathogens or insects. In 2008, major wildfires occurred for the first time in forests affected by SOD. The largest fire, the Basin Complex Fire, ignited from a dry lightning storm in late June and burned over 95,000 ha (USDA Forest Service, 2008). Our study system presents a unique opportunity to study the impacts of a destructive forest disease on a large wildfire. Fig. 2 shows an area affected by pre-fire SOD, and severely damaged by the 2008 Basin Complex Fire.

\subsection{Field data}

A network of long-term SOD monitoring plots ( $500 \mathrm{~m}^{2}$ each) in Big Sur was established in 2006 and 2007 to understand the responses of forest communities (e.g., host mortality) to the invasion of SOD (Meentemeyer et al., 2008). In September and October 2008, immediately following the containment of the Basin fire, we revisited a total of 61 plots to assess burn severities in both infested and uninfested forests. Among these randomly sampled plots, 42 were infected by SOD, while 19 were not (Metz et al., 2011). Plotlevel fire severity was rated using the composite burn index (CBI), a rating from zero to three representing the damage to multiple forest strata as measured across the entire plot. Specifically, we followed Key and Benson (2006) by using a standard CBI data form to measure the depth of ash deposition, charred and intact duff, charred soil, soil with destroyed soil structure, and soil that had been fired to a red color, with details revealed in Metz et al. (2011). The five forest strata evaluated for burn severity included: (1) substrate layer, measured as changes to coarse woody debris, soil, duff, and leaf litter; (2) herb layer, changes or responses of vegetation less than $1 \mathrm{~m}$; (3) shrub layer, changes of vegetation higher than $1 \mathrm{~m}$ but less than $5 \mathrm{~m}$; (4) intermediate-sized tree layer, any trees higher than $5 \mathrm{~m}$ but standing under the dominant trees; and (5) dominant tree layer (Metz et al., 2011). We assessed CBI for the five forest strata and calculated a mean score representing an overall assessment of fire severity (i.e., average $\mathrm{CBI}$ ). Table 1 shows the range (minimum and maximum), mean, median and standard deviation of all the six types of CBI.

\subsection{MASTER imagery}

The MASTER airborne simulator was originally developed to collect ASTER-like and MODIS-like data sets for supporting the validation of ASTER and MODIS algorithms (Hook et al., 2001). MASTER is also similar to one of the two instruments on board the next generation satellite Hyperspectral Infrared Imager (HyspIRI) that offers multitemporal narrow bandwidth VSWIR-MTIR data with global coverage (NASA, 2015). Clearly, studies that employ MASTER airborne simulator offer potential to facilitate future applications of the spaceborne HyspIRI across regional to continental scales. The imagery collected by MASTER included 50 bands covering the visible to shortwave infrared (VNIR-SWIR: bands 1-25), the mid infrared (MIR: bands 26-40), and the thermal infrared (TIR: bands 41-50) regions, with more details found in Hook et al. (2001).

In this study, 12 transects of MASTER images covering the Basin Complex Fire area were collected by NASA-JPL from 12:14 to 14:00 pm on August 26, 2008 (approximately one month after the fire perimeter was contained). The sensor was kept in a small range of altitudes, and had an average ground resolution of $4.0 \mathrm{~m}$. We obtained the MASTER data as a Level 1B product standard that was radiometrically calibrated and geo-located and encapsulated in hierarchical data format. The dimension of each image scene was 716 (the number of pixels) by the number of scan lines by 50 (number of MASTER bands). The scan lines of these 12 images ranged from 2639 to 7539 , and the total number of scan lines was 71,033 . All the images were processed to mitigate the view-angle brightness gradient effect, which was followed by radiometric and topographic corrections (Chen et al., 2015). The mosaicked MASTER image was resampled to $30 \mathrm{~m}$ (facilitating the comparison with Landsat TM imagery), and co-registered with the Landsat TM 2007 image (see more details about Landsat image collection and processing in Section 2.4) yielding a RMSE (root mean squared error) of 0.46 pixels.

\subsection{Landsat imagery}

Two Landsat-5 TM image scenes (path 43, row 35) were acquired on September 16, 2007 and September 2, 2008 from the USGS archive in L1T format (orthocorrected) to represent pre- and postfire forest conditions in the study area. The images had solar zenith angles of $38.9^{\circ}$ and $36.2^{\circ}$, and solar azimuth angles of $144.5^{\circ}$ 
Table 2

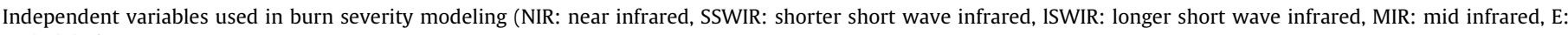
emissivity).

\begin{tabular}{|c|c|c|}
\hline Variable type & Variable name & Description \\
\hline Spectral response - MASTER & $\mathrm{SR}_{\mathrm{iM}}$ & Spectral response of the MASTER's $i$ th band $(i=1, \ldots .50)$ \\
\hline Spectral index - MASTER & $\begin{array}{l}\mathrm{NBR}_{M} \\
\mathrm{NDVI}_{M} \\
\mathrm{NSEV} 1_{M} \\
\mathrm{NSEV} 2_{\mathrm{M}} \\
\mathrm{VI} 3_{\mathrm{M}} \\
\mathrm{SMI}_{M}\end{array}$ & 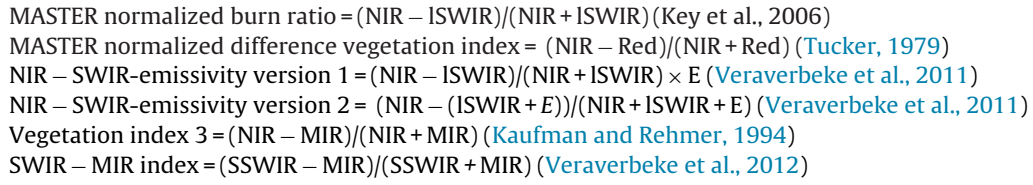 \\
\hline Spectral response - Landsat & $\mathrm{SR}_{i \mathrm{~L}}$ & Spectral response of the 2008 Landsat's $i$ th band $(i=1, \ldots 5,7)$ \\
\hline Spectral index - Landsat & $\begin{array}{l}\mathrm{NBR}_{\mathrm{L}} \\
\mathrm{dNBR}_{\mathrm{L}} \\
\mathrm{NDVI}_{\mathrm{L}} \\
\mathrm{dNDVI}_{\mathrm{L}}\end{array}$ & $\begin{array}{l}\text { Landsat } 2008 \text { NBR } \\
\text { Differenced NBR = Landsat } 2007 \text { NBR - Landsat } 2008 \text { NBR (Wagtendonk et al., 2004) } \\
\text { Landsat } 2008 \text { NDVI } \\
\text { Differenced NDVI = Landsat } 2007 \text { NDVI - Landsat } 2008 \text { NDVI (Xiao et al., 2002) }\end{array}$ \\
\hline
\end{tabular}

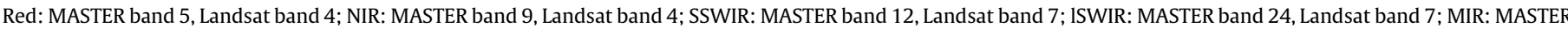
band 29; E: MASTER band 43.

and $135.9^{\circ}$, respectively. For both scenes, bands $1-5$ and 7 were converted to at-sensor radiances, which were then converted to top-of-atmosphere (TOA) reflectance (Chander et al., 2009). The dark object subtraction algorithm was then used to derive surface reflectance (Chavez, 1996), which was followed by topographic correction using the C-correction method and the ASTER-derived DEM data (Teillet et al., 1982; ASTER GDEM Validation Team, 2009). Finally, image-to-image co-registration was conducted using the 2007 Landsat scene as the base. A second-order polynomial warping method and bilinear neighbor resampling were applied based on 40 tie points, yielding a RMSE of 0.16 pixels.

\subsection{Burn severity modeling}

One of the major objectives of this study was to understand the impact of the forest disease SOD on burn severity. To do this, we developed two groups of models to assess burn severity for infested and uninfested forests, respectively. Within each group, we further analyzed the relationships between field-assessed CBI and remote sensing-derived variables for the five forest strata included in the CBI (i.e., substrate, herb, shrub, intermediate-sized tree, and dominant tree layers), as well as the average CBI. We also compared three types of remote sensing models using MASTER plus Landsat bundle, MASTER only, and Landsat only. Consequently, a total of 36 models were developed in our burn severity analysis.

While the dependent variable of burn severity (i.e., $\mathrm{CBI}$ ) was measured in the field, the independent variables were extracted from the remotely sensed data: (i) spectral responses and (ii) spectral indices (Table 2). Specifically, (i) spectral responses include all the 50 bands from the MASTER data, and six bands (i.e., bands $1-5,7$ ) from the 2008 post-fire Landsat image. (ii) Spectral indices extracted from the two sensors were slightly different. For Landsat, we extracted normalized burn ratio (NBR) and normalized difference vegetation (NDVI) from the 2008 post-fire data. Since the 2007 pre-fire Landsat data were available, we further calculated differenced NBR (dNBR) and differenced NDVI (dNDVI). These four indices have been widely used in previous burn severity assessments generating promising results (Tucker, 1979; Xiao et al., 2002). For MASTER, we first extracted NBR and NDVI by following Harris et al. (2011) to select appropriate red, NIR, and ISWIR (longer short wave infrared) bands. It was not possible to calculate dNBR and dNDVI due to the lack of pre-fire data; however, we capitalized on the MASTER's unique MIR and TIR bands and calculated extra four indices: NIR-SWIR-emissivity version 1 and 2 (NSEv1 and NSEv2), Vegetation index 3 (VI3), and SWIRMIR index (SMI) (Kaufman and Rehmer, 1994; Veraverbeke et al., 2011, 2012). Specifically, VI3 and SMI were developed to employ the MIR spectral region and revealed high robustness against the presence of smoke, while NSEv1 and NSEv2 were created to incorporate emissivity from the thermal bands and showed relatively strong potential for discriminating immediate post-fire burned areas. Please refer to Table 2 for detailed equations and bands used.

Multiple linear regression models were developed to estimate burn severity from the remote sensing predictors. The rationale of choosing multiple regression was due to its wide application in burn severity mapping generating satisfactory results (e.g., Miller and Thode, 2007; Harris et al., 2011). However, we also note that physical models and machine learning approaches have been used for similar mapping purposes (e.g., De Santis et al., 2007; Hultquist et al., 2014 Hultquist et al., 2014). To avoid the overfitting problem common to regression models and reduce multicollinearity, correlation coefficients were first calculated between all independent (i.e., spectral responses and indices) and dependent (i.e., CBI) variables. Each independent variable was evaluated and retained under two rules: (1) its correlation value with any other independent variable should be lower than 0.7 ; or (2) if its correlation with another one or several independent variables is higher than 0.7 , the variable should have the highest correlation value with the field-measured CBI of all these variables (Chen et al., 2011). After discarding redundant independent variables, a forward stepwise method was used in the regression analysis to develop models at a 0.05 significance level. To calibrate models, we randomly selected $50 \%$ of the field data (i.e., $50 \%$ of the infested and uninfested plots, respectively), while the remainder was used in model validation.

Once the burn severity models were developed from the ground-truthed observations in 61 plots, they were applied separately in infested and uninfested forests based on a tree mortality map produced by Meentemeyer et al. (2008) who estimated the number of trees killed by SOD measured using high-resolution aerial images calibrated with field data. Apparently, the forest infestation status was acquired prior to the fire event.

\section{Results and discussion}

\subsection{Comparison between Landsat and MASTER}

We compared coefficient of determination $\left(R^{2}\right)$ from all of the developed regression models using Landsat, MASTER, and the synergy of Landsat and MASTER for (a) infested and (b) uninfested forests (Fig. 3). Similar trends were found in both types of forests. Specifically, Landsat and MASTER, as well as the combined data set, improved the performance of assessing burn severity (i.e., reaching highest $R^{2}$ values) at the dominant tree layer, which was the top layer of the five tested forest strata. The model performance 


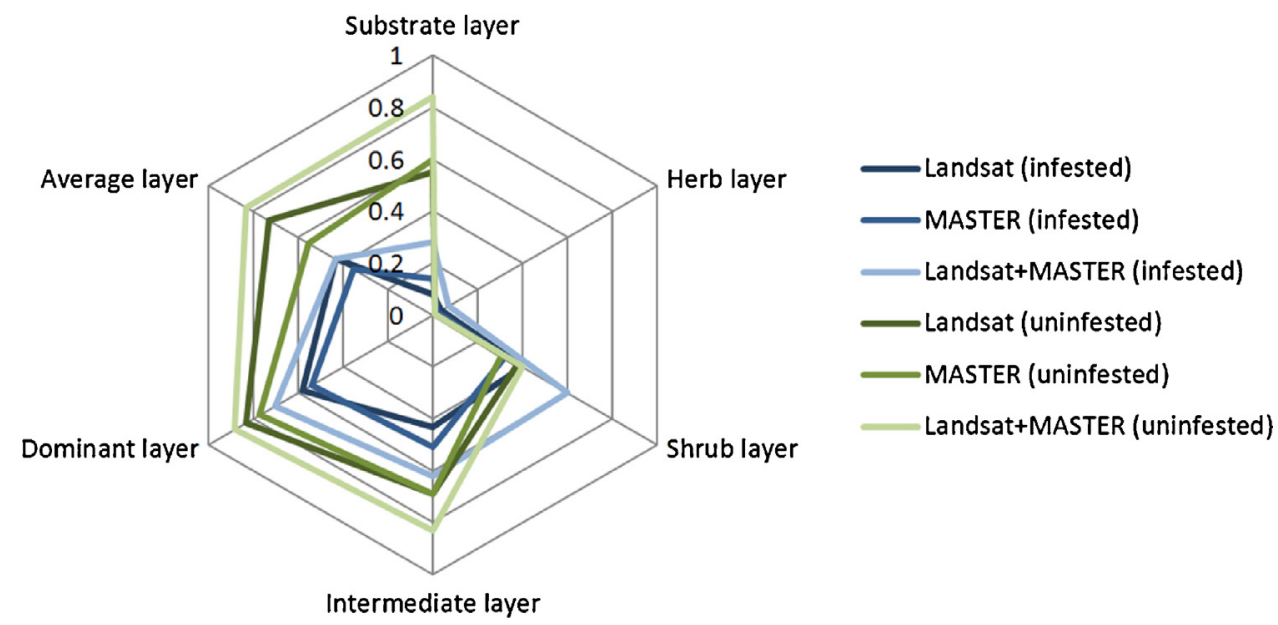

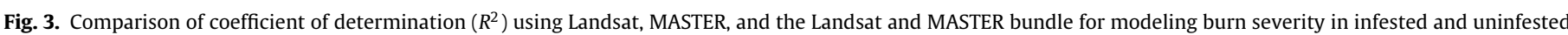
forests.

progressively decreased from the relatively high intermediatesized tree layer, the shrub layer to the low substrate layer. This was expected as the signals received by remotely sensed optical sensors are typically biased to the upper level of forest canopies (Chen et al., 2012). For the herb layer (vegetation less than $1.0 \mathrm{~m}$ in height), both Landsat and MASTER performed poorly, with $R^{2}$ close to 0 . Besides the factor of low signal penetration rate, one particular reason was that burn severity at this layer was very high (e.g., max CBI of 3.0 ) in $80 \%$ the field plots, with mean and median CBI values close or equal to 3.0 (Table 1). Because of such high CBI values for all plots, no trends were present in the data for this layer. In the following sections, herb layer will be removed from our discussion. We further found that the estimation of average CBI, representing an overall assessment of burn severity of all layers, showed average performance among all the models developed (Fig. 3).

In addition, Fig. 3 shows that the combination of Landsat and MASTER consistently generated better results than using Landsat or MASTER only for almost all the evaluated forest strata. For infested forests, on average, the data combination improved the model performance by $14-15 \%$ in $R^{2}$ compared to the use of Landsat or MASTER, while the model RMSE decreased by 0.04-0.06. Similarly, for uninfested forests, the average model improvements were $13 \%$ and $17 \%$ in $R^{2}$, with decreases of 0.06 and 0.10 in RMSE. Clearly, the combination of Landsat and MASTER demonstrated high potential to improve burn severity assessment in both types of forests with and without disease infection. However, the comparison between Landsat and MASTER showed slightly different trends (Fig. 3). For uninfested trees, the application of Landsat had better model performance in almost all the forest strata (except the substrate layer), with an average increase of $5 \%$ in $R^{2}$ and a decrease of 0.06 in RMSE. For infested trees, while Landsat outperformed MASTER at the shrub, dominant and average tree layers, MASTER was better for estimating burn severity at the substrate and intermediatesized tree layers (Fig. 3). The comparisons confirmed the high value of applying the typical pre- and post-fire Landsat data bundle in burn severity mapping, while MASTER data with a higher spectral resolution and extra mid-thermal bands may outperform Landsat under certain circumstances (e.g., the intermediate-sized layer in infested forests). However, we noted that the addition of MASTER to Landsat provided the best solution (i.e., higher model $R^{2}$ and lower RMSE) compared to the use of MASTER or Landsat data only (Fig. 3).

Scatter plots of the burn severity modeled by Landsat and/or MASTER data versus field validation measurements are presented in Figs. 4 and 5, representing infested and uninfested forests, respectively. Similar to our findings during model calibration (Fig. 3), burn severity assessments using the combination of Landsat and MASTER showed better results (i.e., higher agreements with field measurements) than those using data from individual sensors for most of the evaluated forest strata, and burn severity at the dominant tree layer was found to be more accurate to estimate (Figs. 4 and 5). However, exceptions remained. For example, data combination did not improve the model performance at the substrate and average layers, with estimation results even poorer than using Landsat only for the infested forests (Fig. 4). This can be explained by the low variance of burn severity CBI values acquired from the infested forests, where the addition or subtraction of individual field measures may have significantly affected model performance, resulting in less robust models. Especially for the understory layers, SOD increased fuel loads (Metz et al., 2011), which was expected to be the main reason causing similar burn effects with low variance. Compared to uninfested forests, infested stands clearly introduced higher variation to forest spectral reflectance, making it challenging to remotely sense burn severity in diseased trees.

To explore the potential reasons why the models combining both Landsat and MASTER data sets led to improved burn severity assessments in the evaluated forest landscape, we analyzed the independent variables that have significantly contributed to the integrated models. Table 3 shows that Landsat-derived variables (e.g., NDVI, NBR, dNBR, red and NIR bands) still played a critical role in burn severity estimation in both infested and uninfested forests. Similar to several previous findings, this may be explained by the fact that fire can cause remarkable decreases in chlorophyll content and vegetation moisture leading to lower visible and NIR reflectance and higher SWIR reflectance (White et al., 1996; De Santis and Chuvieco, 2007). Among these variables, the most common one was NDVI that appeared in five of the total 10 models and was negatively correlated with burn severity (Table 3). Surprisingly, this finding is slightly different from some of those in the literature, where NBR or dNBR, rather than NDVI, extracted from the NIR-SWIR bands showed stronger correlations with CBI (De Santis and Chuvieco, 2007). Because our study area was located in a mountainous coastal region, it was possible that microclimates led to high variation in vegetation water content, thus increasing variation in the SWIR spectral bands and NBR and dNBR values.

We further found improved model performance using post-fire Landsat and MASTER data, as opposed to the typical pre- and postfire Landsat bundle for estimating burn severity, because most 

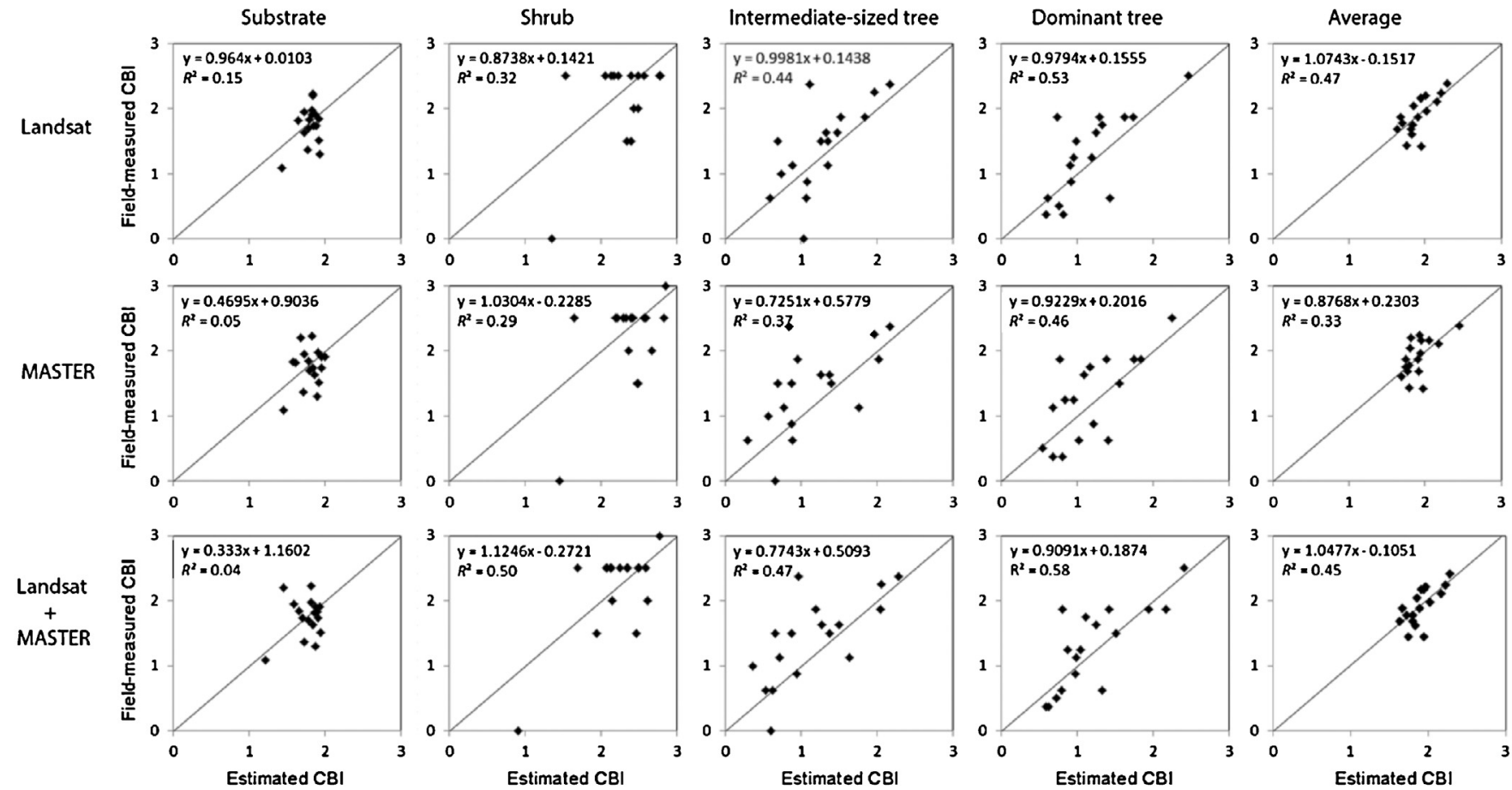

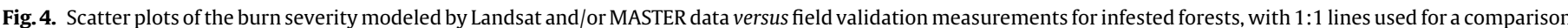
purpose.

of the independent variables used in the final integrated models were based on the 2008 data (Table 3). Compared to Landsat, the unique features of MASTER data laid in two aspects: (i) higher spectral resolution (i.e., 25 MASTER bands versus six Landsat bands in VNIR-SWIR), and (ii) extra 25 MIR-TIR bands. Thus, it was meaningful to investigate whether these features can exert positive impacts on burn severity mapping. In Table 3, we found that 12 variables from the MASTER sensor (versus five variables from Landsat) contributed to the burn severity assessments. Specifically, four variables were within VNIR-SWIR, with five variables from MIR-TIR, and three spectral indices (i.e., $\mathrm{NSEv}_{\mathrm{M}}, \mathrm{SMI}_{\mathrm{M}}$ and $\mathrm{NDVI}_{\mathrm{M}}$ ) derived from both the VNIR-SWIR, MIR-TIR spectral ranges. The reason that a larger number of MASTER-derived variables showed significance in the final models could be explained by the fact that the MASTER narrow spectral bands were sensitive to the changes in forest conditions. Even if such changes were subtle, the variables that had a higher ability to explain variance in burn severity may vary, probably shifting to other variables when modeling different forest strata. Results also revealed the significant contributions of several unique indices (e.g., $\mathrm{NSEv}_{\mathrm{M}}$ and $\mathrm{SMI}_{\mathrm{M}}$ ) that were derived from the MASTER's MIR-TIR bands. These extended spectral ranges were possibly robust against fire smoke-caused scattering enabling a 'clear' view of ground burn severity, similar to the findings discovered by Veraverbeke et al. (2012).

Hence, we may conclude that (i) high spectral resolution MASTER data (using extended MIR-TIR spectral bands) have the

Table 3

Burn severity models using synergized Landsat and MASTER data for multiple forest strata (except the herb layer).

\begin{tabular}{|c|c|}
\hline Forest layer & Model \\
\hline Substrate & $\begin{array}{l}Y_{\text {Infested }}=1.14+21.65 \times \mathrm{NBR}_{\mathrm{L}}+0.94 \times \mathrm{SMI}_{\mathrm{M}} \\
Y_{\text {Uninfested }}=-39.1-17.73 \times \mathrm{DN}_{3 \mathrm{~L}}-6.28 \times \mathrm{DN}_{4 \mathrm{~L}}+15.46 \times \mathrm{DN}_{34 \mathrm{M}}+32.56 \times \mathrm{DN}_{48 \mathrm{M}}+2.49 \times \mathrm{NSEv} 1_{\mathrm{M}}\end{array}$ \\
\hline Shrub & $\begin{array}{l}Y_{\text {Infested }}=0.91+10.54 \times \mathrm{DN}_{11 \mathrm{M}}-10.57 \times \mathrm{DN}_{23 \mathrm{M}}-9.06 \times \mathrm{NDVI}_{\mathrm{M}} \\
Y_{\text {Uninfested }}=11.50+5.33 \times \mathrm{DN}_{3 \mathrm{~L}}-3.90 \times \mathrm{NDVI}_{\mathrm{L}}-16.76 \times \mathrm{DN}_{18 \mathrm{M}}\end{array}$ \\
\hline Intermediate-sized tree & $\begin{array}{l}Y_{\text {Infested }}=-15.62-2.81 \times \mathrm{NDVI}_{\mathrm{L}}-3.91 \times \mathrm{DN}_{18 \mathrm{M}}+21.72 \times \mathrm{DN}_{49 \mathrm{M}} \\
Y_{\text {Uninfested }}=-9.39-3.40 \times \mathrm{NDVI}_{\mathrm{L}}+4.93 \times \mathrm{DN}_{17 \mathrm{M}}+11.43 \times \mathrm{DN}_{36 \mathrm{M}}\end{array}$ \\
\hline Dominant tree & $\begin{array}{l}Y_{\text {Infested }}=1.44+3.32 \times \mathrm{DN}_{5 \mathrm{~L}}-1.32 \times \mathrm{NBR}_{\mathrm{L}}-2.25 \times \mathrm{NSEV}_{\mathrm{M}} \\
Y_{\text {Uninfested }}=-12.82-3.10 \times \mathrm{NDVI}_{\mathrm{L}}+21.68 \times \mathrm{DN}_{34 \mathrm{M}}-3.98 \times \mathrm{DN}_{42 \mathrm{M}}\end{array}$ \\
\hline Average & $\begin{array}{l}Y_{\text {Infested }}=2.72-1.62 \times \mathrm{NDVI}_{\mathrm{L}}+0.22 \times \mathrm{DN}_{18 \mathrm{M}} \\
Y_{\text {Uninfested }}=4.66+1.61 \times \mathrm{dNBR}_{\mathrm{L}}+0.04 \times \mathrm{DN}_{11 \mathrm{M}}+14.62 \times \mathrm{DN}_{34 \mathrm{M}}-18.11 \times \mathrm{DN}_{42 \mathrm{M}}\end{array}$ \\
\hline
\end{tabular}

$\mathrm{dNBR}_{\mathrm{L}}=$ Landsat differenced normalized burn ratio;

$\mathrm{SR}_{i \mathrm{~L}}=$ Spectral response of the 2008 Landsat's $i$ th band $(i=1, \ldots .5,7)$;

$\mathrm{NBR}_{\mathrm{L}}=$ Landsat 2008 normalized burn ratio;

$\mathrm{NDVI}_{\mathrm{L}}=$ Landsat 2008 normalized difference vegetation index;

$\mathrm{SR}_{i \mathrm{M}}=$ Spectral response of the MASTER's $i$ th band $(i=1, \ldots .50)$;

$\mathrm{SMI}_{\mathrm{M}}=$ MASTER SWIR-MIR index;

$\mathrm{NDVI}_{\mathrm{M}}=$ MASTER normalized difference vegetation index;

NSEv1 $1_{M}=$ MASTER NIR-SWIR-emissivity version 1;

SWIR = Shortwave infrared;

MIR = Mid infrared. 

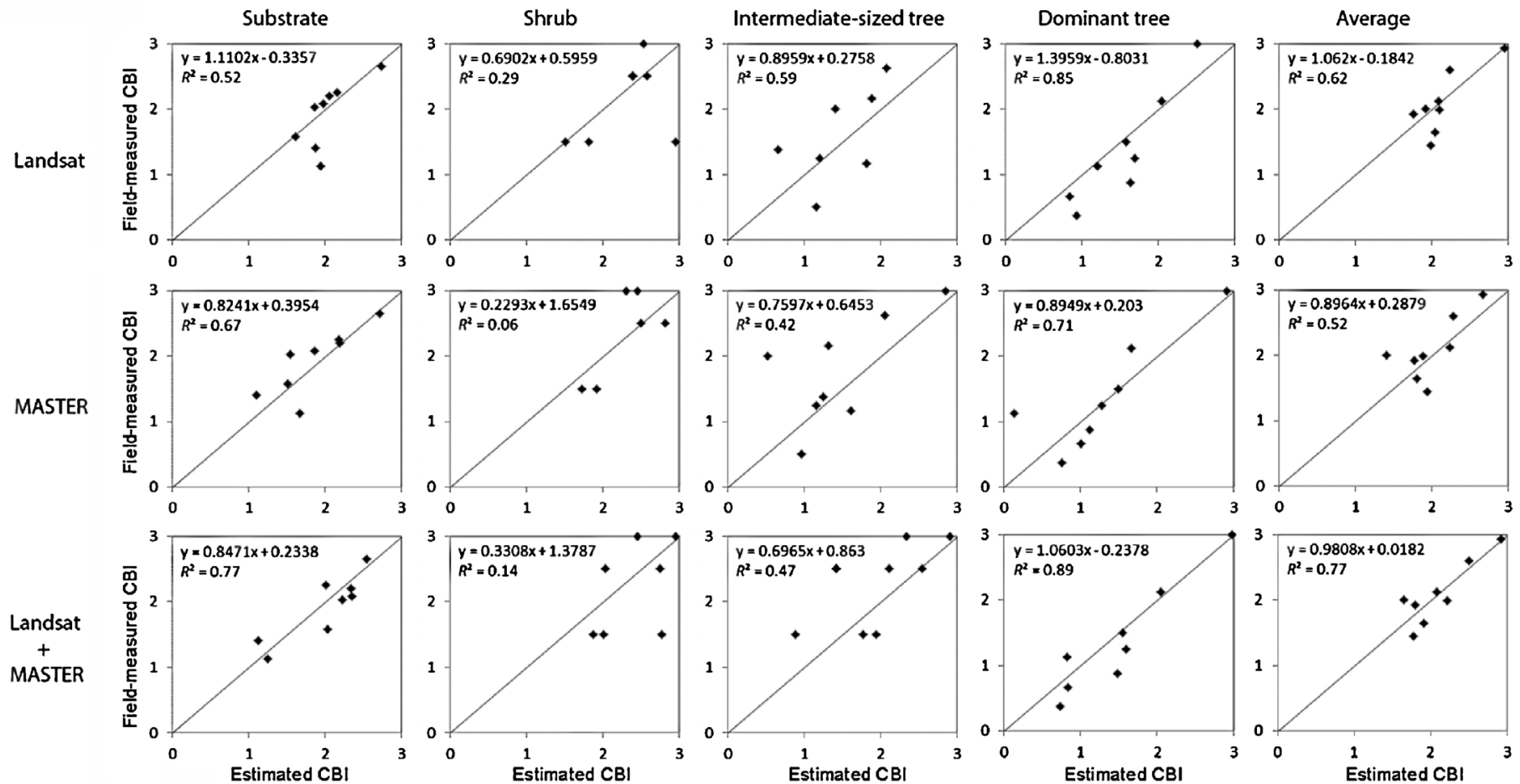

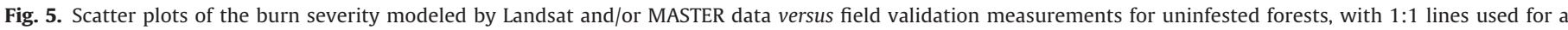
comparison purpose.

potential to augment the performance of applying Landsat imagery to assess forest burn severity in both healthy and diseased trees; and (ii) the combination of MASTER and Landsat data collected after fire disturbances may retain or even improve the performance of burn severity estimation using the typical pre- and post-fire Landsat data bundle, facilitating landscape-scale forest fire management if pre-fire high-quality remote sensing data are not possible to obtain.

\subsection{Comparison between infested and uninfested forests}

As discussed in the previous section, data combination using Landsat and MASTER demonstrated high potential to improve the accuracy of assessing burn severity than using individual sensors in both infested and uninfested forests. And among all the forest strata evaluated, the dominant tree layer generated the most accurate results. Hence, the following comparisons of burn effects

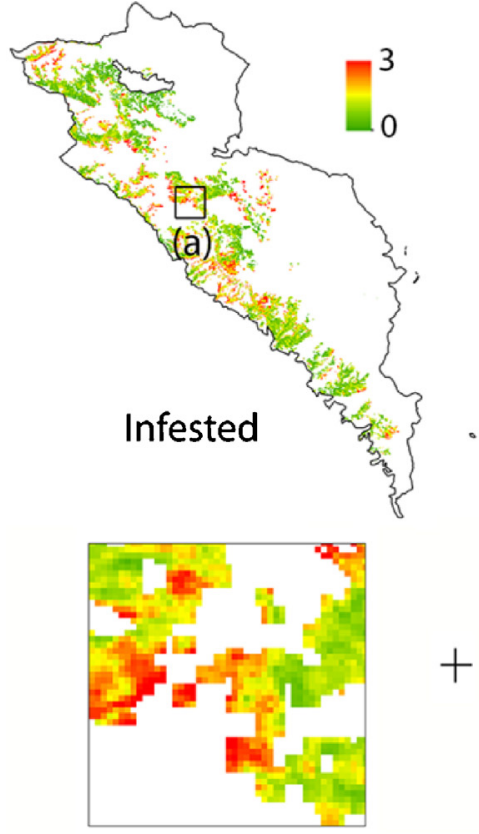

(a)
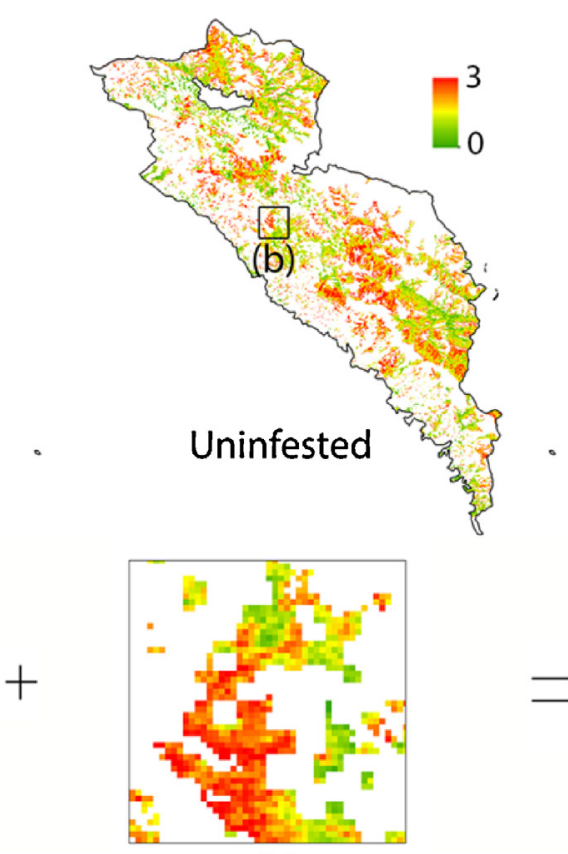

(b)
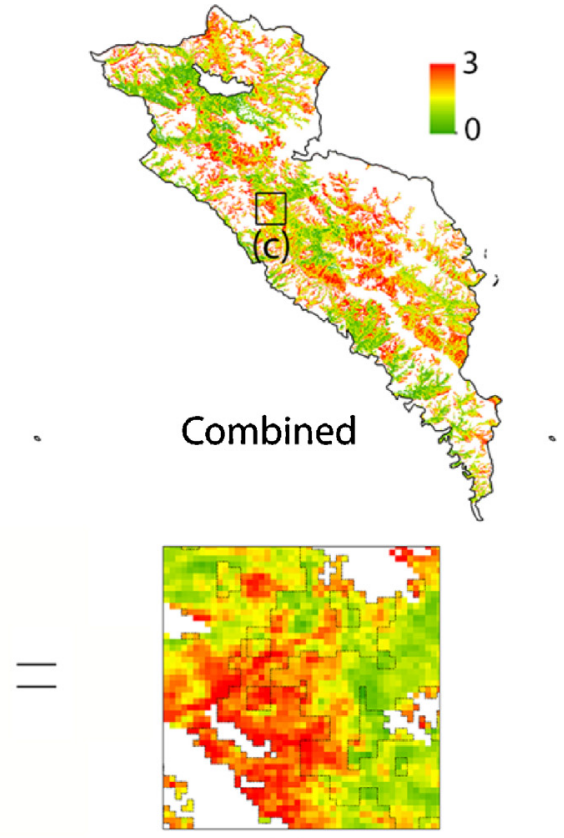

(c)

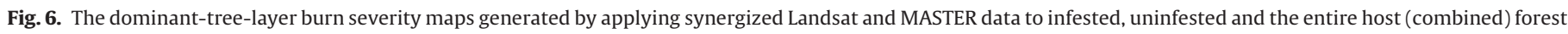

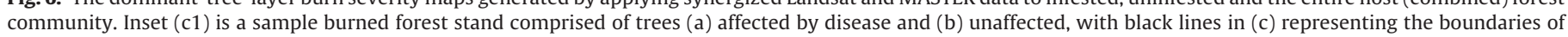
these two communities. 
Table 4

Summary statistics (i.e., area, percentage of total area, minimum, maximum, mean, median and standard deviation) of the burn severity in forests affected by the disease.

\begin{tabular}{|c|c|c|c|c|c|c|c|}
\hline Burn severity & $\begin{array}{l}\text { Area } \\
\text { (ha) }\end{array}$ & $\begin{array}{l}\text { Percentage of total area } \\
(\%)\end{array}$ & Minimum & Maximum & Mean & Median & Standard deviation \\
\hline Low $(0-1)$ & 3528.5 & 61.2 & 0.00 & 0.99 & 0.41 & 0.42 & 0.33 \\
\hline Moderate (1-2) & 1579.8 & 27.4 & 1.00 & 1.99 & 1.41 & 1.37 & 0.28 \\
\hline $\operatorname{High}(2-3)$ & 654.4 & 11.4 & 2.00 & 3.00 & 2.51 & 2.47 & 0.33 \\
\hline
\end{tabular}

Table 5

Summary statistics (i.e., area, percentage, minimum, maximum, mean, median and standard deviation) of the burn severity in forests without disease invasion.

\begin{tabular}{|c|c|c|c|c|c|c|c|}
\hline Burn severity & $\begin{array}{l}\text { Area } \\
\text { (ha) }\end{array}$ & $\begin{array}{l}\text { Percentage } \\
(\%)\end{array}$ & Minimum & Maximum & Mean & Median & Standard deviation \\
\hline Low $(0-1)$ & 5511.9 & 38.7 & 0.00 & 0.99 & 0.16 & 0.00 & 0.32 \\
\hline Moderate (1-2) & 5017.1 & 35.2 & 1.00 & 1.99 & 1.52 & 1.53 & 0.28 \\
\hline $\operatorname{High}(2-3)$ & 3722.0 & 26.1 & 2.00 & 3.00 & 2.44 & 2.40 & 0.30 \\
\hline
\end{tabular}

only focus on applying the integrated models (Table 3) to the dominant tree layer. Fig. 6 shows three burn severity maps for infested, uninfested and the entire (combined) forest community. A rainbow legend was used, with green color indicating low severity of burns, red color showing severe burns, and white color representing non-forested lands. Inset (c) is a sample burned forest stand comprised of trees (a) affected by disease and (b) those that were not, with black lines in (c) representing the boundaries of these two communities. Surprisingly, burn severity unveiled a smooth transition on the boundaries of infested and uninfested stands (Fig. 6), with similar phenomenon observed in many other locations of the study area. While it was expected that burn severity may increase in infested forests as a result of reduced foliar moisture content and increased forest fuels, such phenomenon was not clearly exposed in the burn severity map created in our study. Besides infestation, we found that complex local microclimates (e.g., caused by topography) may also play a role in determining burn severity (Lee et al., 2009).

To quantify the differences in burn severity between infested and uninfested forests, we summarized their area, percentage, minimum, maximum, mean, median and standard deviation for three burn severity categories of low $(\mathrm{CBI} \epsilon[0,1])$, moderate $(\mathrm{CBI} \in[1,2])$ and high $(\mathrm{CBI} \in[2,3])$, respectively (Tables 4 and 5 ). In this research, we found that a higher area percentage of low-severity burns and a smaller area percentage of high-severity burns occurred in infested than uninfested forests (i.e., low: $61.2 \%$ versus $38.7 \%$; high: $11.4 \%$ versus $26.1 \%$ ). This could be explained by two facts. First, most of the infested trees were within the narrow strip in the west of the study area (Fig. 6), as a consequence of SOD invasion starting from the coast of Pacific Ocean in the west (Rizzo et al., 2005). However, the uninfested trees still occupied a large portion of the area, i.e., 6.3 times larger than the coverage of the infested forests (Fig. 6). Second, most of the severe burns occurred in the central part of our study area, out of the distributions of the majority of infested trees (Fig. 6). In terms of the comparison of the same level of burn severity, we found similar statistical results (i.e., similar mean, median and standard deviation) within the two categories of moderate and high levels of burns for both infested and uninfested forests (Tables 4 and 5). However, the results also showed that in the category of low burn severity, uninfested forests tended to have a much lower burn effect than that in infested forests (e.g., mean: 0.16 versus 0.41 ; median: 0.00 versus 0.42 ). This was possibly due to the higher water content in healthy tree leaves that were more resilient to small fires.

\section{Conclusions}

Today's forest ecosystems are increasingly affected by a variety of disturbances including fires and emerging infectious diseases, which makes it challenging to accurately assess post-fire burn severity. In this study, we evaluated the performance of using (pre- and post-fire) Landsat and (post-fire) MASTER data to assess burn severity in a California coastal forest ecosystem, which has been affected by a non-native infectious disease SOD since the mid-1990s. Results showed that the combination of Landsat and MASTER consistently generated better results than those using Landsat or MASTER only in almost all the evaluated forest strata (e.g., substrate, shrubs, intermediate-sized trees, dominant trees and the average), among which the best result was achieved at the dominant tree layer. The application of MASTER MIR and TIR spectral bands (3.0-12.5 $\mu \mathrm{m}$ ) was found to augment burn severity assessments from Landsat for both uninfested and diseased forests. We further found improved model performance using integrated MASTER and Landsat data collected after the fire event, rather than the typical pre- and post-fire Landsat bundle, suggesting that postfire high spectral resolution MASTER data may have the potential to retain or even improve the burn severity estimation accuracy if prefire high-quality remote sensing data are not possible to obtain (e.g., due to high percent cloud cover). It was also discovered that the burn severity models developed for the uninfested forests outperformed the ones for the infested trees, indicating that the invasion of SOD has introduced high spectral variation to local forests, where single sensors and simple models (e.g., linear regression) may not be sufficient to fully describe the complex relationship between remotely sensed spectral reflectance and burn severity. In addition, statistical results showed that both the infested and uninfested forests similarly experienced moderate and high levels of burns $(\mathrm{CBI}>1)$. The difference occurred in the forests with low burn severity $(\mathrm{CBI}<1)$, where uninfested trees had a much lower burn effect than that in infested trees, possibly due to the fact that healthy tree with higher water content and less fuels were more resilient to small fire disturbances. Because several factors (e.g., the characteristics of data and study area) may affect our findings, future research is needed to verity the robustness of combining high-spectral MASTER and multi-date Landsat in burn severity assessment over other diseased forests.

\section{Acknowledgements}

This research was supported by the National Science Foundation (EF-0622770) as part of the joint NSF-NIH Ecology and Evolution of Infectious Disease program. The authors also gratefully acknowledge financial support from the USDA Forest Service - Pacific Southwest Research Station, the Gordon \& Betty Moore Foundation, and support to Dr. Gang Chen from North Carolina Space Grant, and UNC Charlotte through the CLAS Junior Faculty Development Award. We also thank numerous contributors who provided vital field and laboratory support, including K. Aram, M. Beh, A. Brauer, M. Chan, R. Cobb, C. DeLong, W. Dillon, K. Frangioso, A. Hohl, H. 
Mehl, A. Oguchi, E. Paddock, K. Pietrzak, M. Vaclavikova, J. Vieregge, L. Waks and A. Wickland.

\section{References}

ASTER GDEM Validation Team, 2009. ASTER Global DEM Validation: Summary Report. June 2009. Available online: https://lpdaac.usgs.gov/sites/default/files/ public/aster/docs/ASTER_GDEM_Validation_Summary_Report.pdf

Asner, G.P., 2013. Geography of forest disturbance. Proc. Natl. Acad. Sci. U.S.A. 110 3711-3712.

Bergot, M., Cloppet, E., Pérarnaud, V., Déqué, M., Marcais, B., Desprez-Loustau, M.-L., 2004. Simulation of potential range expansion of oak disease caused by Phytophthora cinnamomi under climate change. Global Change Biol. 10, 1552-1939.

Carcaillet, C., Bergeron, Y., Richard, P.J.H., Fréchette, B., Gauthier, S., Prairie, Y.T., 2001. Change of fire frequency in the eastern Canadian boreal forests during the Holocene: does vegetation composition or climate trigger the fire regime? J. Ecol. 89, 930-946.

Chander, G., Markham, B.L., Helder, D.L., 2009. Summary of current radiometric calibration coefficients for Landsat MSS, TM, ETM+, and EO-1 ALI sensors. Remote Sens. Environ. 113, 893-903.

Chavez, P., 1996. Image-based atmospheric corrections - Revisited and improved. Photogramm. Eng. Remote Sens. 62, 1025-1036.

Chen, G., Hay, G.J., Castilla, G., St-Onge, B., Powers, R., 2011. A multiscale geographic object-based image analysis to estimate lidar-measured forest canopy height using Quickbird imagery. Int. J. Geogr. Inf. Sci. 25, 37-41.

Chen, G., Wulder, M.A., White, J.C., Hilker, T., Coops, N.C., 2012. Lidar calibration and validation for geometric-optical modeling with Landsat imagery. Remote Sens. Environ. 124, 384-393.

Chen, G., Metz, M.R., Rizzo, D.M., Dillon, W.W., Meentemeyer, R.K., 2015 Object-based assessment of burn severity in diseased forests using high-spatial and high-spectral resolution MASTER airborne imagery. ISPRS J. Photogramm. Remote Sens. 102, 38-47.

Davis, F.W., Borchert, M.I., Flint, A., Meentemeyer, R.K., Rizzo, D.M., 2010. Pre-impact forest composition and ongoing tree mortality associated with sudden oak death disease in the Big Sur region, California. For. Ecol. Manage. 259, 2342-2354.

De Santis, A., Chuvieco, E., 2007. Burn severity estimation from remotely sensed data: performance of simulation versus empirical models. Remote Sens. Environ. 108, 422-435.

Epting, J., Verbyla, D., Sorbel, B., 2005. Evaluation of remotely sensed indices for assessing burn severity in interior Alaska using Landsat TM and ETM+. Remote Sens. Environ. 96, 328-339.

Fox, D.M., Maselli, F., Carrega, P., 2008. Using SPOT images and field sampling to map burn severity and vegetation factors affecting post forest fire erosion risk CATENA 75, 326-335.

Hall, D.K., Ormsby, J.P., Johnson, L., Brown, J., 1980. Landsat digital analysis of the initial recovery of burned tundra at Kokolik River, Alaska. Remote Sens. Environ. 10, 263-272

Harris, S., Veraverbeke, S., Hook, S., 2011. Evaluating spectral indices for assessing fire severity in Chaparral ecosystems (Southern California) using MODIS/ASTER (MASTER) airborne simulator data. Remote Sens. 3 2403-2419.

Hook, S.J., Myers, J.J., Thome, K.J., Fitzgerald, M., Kahle, A.B., 2001. The MODIS/ASTER airborne simulator (MASTER) - a new instrument for earth science studies. Remote Sens. Environ. 76, 93-102.

Hudak, A.T., Brockett, B.H., 2004. Mapping fire scars in a southern African savanna using Landsat imagery. Int. J. Remote Sens. 25, 3231-3243.

Hultquist, C., Chen, G., Zhao, K., 2014. A comparison of Gaussian process regression: random forests and support vector regression for burn severity assessment in diseased forests. Remote Sens. Lett. 5, 723-732.

Jakubauskas, M.E., Lulla, K.P., Mausel, P.W., 1990. Assessment of vegetation change in a fire-altered forest landscape. Photogramm. Eng. Remote Sens. 56 371-377.

Jenkins, M.J., Hebertson, E., Page, W., Jorgensen, C.A., 2008. Bark beetles fuels, fires and implications for forest management in the Intermountain West. For. Ecol. Manage. 254, 16-34

Kaufman, Y., Rehmer, L., 1994. Detection of forests using mid-IR reflectance: an application for aerosol studies. IEEE Trans. Geosci. Remote Sens. 32, 672-683.

Keeley, J.E., 2009. Fire intensity, fire severity and burn severity: a brief review and suggested usage. Int. J. Wildland Fire 18, 116-126.

Key, C., Benson, N., 2006. Landscape assessment: ground measure of severity; the composite burn index, and remote sensing of severity, the normalized burn index. In: Lutes, D., Keane, R., Caratti, J., Key Benson, C., Sutherland, N., Gangi, S.L. (Eds.), FIREMON: Fire Effects Monitoring and Inventory System. Rocky Mountains Research Station USDA Forest Service, Fort Collins, CO, USA, pp. $1-51$.

Kokaly, R.F., Rockwell, B.W., Haire, S.L., King, T.V.V., 2007. Characterization of post-fire surface cover, soils, and burn severity at the Cerro Grande Fire, New Mexico, using hyperspectral and multispectral remote sensing. Remote Sens. Environ. 106, 305-325.

Kurz, W.A., Stinson, G., Rampley, G., 2008a. Could increased boreal forest ecosystem productivity offset carbon losses from increased disturbances? Philos. Trans. R. Soc. B 363, 2259-2268.
Kurz, W.A., Dymond, C.C., Stinson, G., Rampley, G.J., Neilson, E.T., Carroll, A.L., Ebata, T., Safranyik, L., 2008b. Mountain pine beetle and forest carbon feedback to climate change. Nature 452, 987-990.

Lamsal, S., Cobb, R.C., Hall Cushman, J., Meng, Q., Rizzo, D.M., Meentemeyer, R.K., 2011. Spatial estimation of the density and carbon content of host populations for Phytophthora ramorum in California and Oregon. For. Ecol. Manage. 262, 989-998.

Lee, S.-W., Lee, M.-B., Lee, Y.-G., Won, M.-S., Kim, J.-J., Hong, S., 2009. Relationship between landscape structure and burn severity at the landscape and class levels in Samchuck, South Korea. For. Ecol. Manage. 258, 1594-1604.

Lentile, L.B., Holden, Z.A., Smith, A.M.S., Falkowski, M.J., Hudak, A.T., Morgan, P. Lewis, A.A., Gessler, P.E., Benson, N.C., 2006. Remote sensing techniques to assess active fire characteristics and post-fire effects. Int. J. Wildland Fire 15, 319-345.

Meentemeyer, R.K., Rank, N.E., Shoemaker, D., Oneal, C., Wickland, A.C., Frangioso, K.M., Rizzo, D.M., 2008. Impacts of sudden oak death on tree mortality in the Big Sur ecoregion of California. Biol. Invasions 10, 1243-1255.

Meentemeyer, R.K., Haas, S.E., Vaclavik, T., 2012. Landscape epidemiology of emerging infectious diseases in natural and human-altered ecosystems. Annu. Rev. Phytopathol. 50, 379-402.

Metz, M.R., Frangioso, K.M., Meentemeyer, R.K., Rizzo, D.M., 2011. Interacting disturbances: wildfire severity affected by stage of forest disease invasion. Ecol. Appl. 21, 313-320.

Metz, M.R., Frangioso, K., Meentemeyer, R.K., Rizzo, D.M., 2012. An emergent disease causes directional changes in forest species composition in coastal California. Ecosphere 3, art86.

Metz, M.R., Varner, J.M., Frangioso, K.M., Meentemeyer, R.K., Rizzo, D.M., 2013. Unexpected redwood mortality from synergies between wildfire and an emerging infectious disease. Ecology 94, 2152-2159.

Miller, J.D., Thode, A.E., 2007. Quantifying burn severity in a heterogeneous landscape with a relative version of the delta normalized burn ratio (dNBR). Remote Sens, Environ. 109, 66-80.

Miller, J.D., Yool, S.R., 2002. Mapping forest post-fire canopy consumption in several overstory types using multi-temporal Landsat TM and ETM data. Remote Sens. Environ 82, 481-496.

Milne, A.K., 1986. The use of remote sensing in mapping and monitoring vegetational change associated with bushfire events in Eastern Australia. Geocarto Int. 1, 25-32.

Morton, D.C., Le Page, Y., DeFries, R., Collatz, G.J., Hurtt, G.C., 2013. Undestorey fire frequency and the fate of burned forests in southern Amazonia. Philos. Trans. R. Soc. B 368, 20120163

NASA, 2015. HyspIRI Mission Study. Available online: http://hyspiri.jpl.nasa.gov

Wildland fire in ecosystems: effects of fire on soils and water Neary, D.G., Ryan, K.C., Debano, L.F. (Eds.), 2005. Gen. Tech. Rep. RMRS-GTR-42-, vol. 4. UT: U.S. Department of Agriculture, Forest Service, Rocky Mountain Research Station, Ogden, pp. 5-17.

Olsson, P.-O., Jönsson, A.M., Eklundh, L., 2012. A new invasive insect in Sweden Physokermes inopinatus: tracing forest damage with satellite based remote sensing. Forest Ecol. Manage. 285, 29-37.

Pan, Y., Birdsey, R.A., Fang, J., et al., 2011. A large and persistent carbon sink in the world's forests. Science 333, 988-993.

Quintano, C., Fernández-Manso, A., Roberts, D.A., 2013. Multiple endmember spectral mixture analysis (MESMA) to map burn severity levels from Landsat images in Mediterranean countries. Remote Sens. Environ. 136, 76-88.

Rizzo, D.M., Garbelotto, M., Hansen, E.M., 2005. Phytophthora ramorum: integrative research and management of an emerging pathogen in California and Oregon forests. Annu. Rev. Phytopathol. 43, 309-335

Roy, D.P., Boschetti, L., Trigg, S., 2006. Remote sensing of fire severity: assessing the performance of the normalized burn ratio. IEEE Trans. Geosci. Remote Sens. Lett. 3, 112-116.

Teillet, P.M., Guindon, B., Goodenough, D.G., 1982. On the slope-aspect correction of multispectral scanner data. Can. J. Remote Sens. 8, 84-106.

Tucker, C., 1979. Red and photographic infrared linear combinations for monitoring vegetation. Remote Sens. Environ. 8, 127-150.

Turner, M.G., Baker, W.L., Peterson, C.J., Peet, R.K., 1998. Factors influencing succession: lessons from large, infrequent natural disturbances. Ecosystems 1, 511-523.

USDA Forest Service, 2008. Executive Summary: Basin Complex Fire/Indians Fire BAER Initial Assessment. USDA Forest Service, pp. 16

Veraverbeke, S., Harris, S., Hook, S., 2011. Evaluating spectral indices for burned area discrimination using MODIS/ASTER (MASTER) airborne simulator data. Remote Sens. Environ. 115, 2702-2709.

Veraverbeke, S., Hook, S., Hulley, G., 2012. An alternative spectral index for rapid fire severity assessments. Remote Sens. Environ. 123, 72-80.

Westerling, A.L., Hidalgo, H.G., Cayan, D.R., Swetnam, T.W., 2006. Warming and earlier spring increase western US forest wildfire activity. Science 313, 940-943.

White, J.D., Ryan, K.C., Key, C.C., Running, S.W., 1996. Remote sensing of forest fire severity and vegetation recovery. Int. J. Wildland Fire 6, 125-136.

Wulder, M.A., Dymond, C.C., White, J.C., Leckie, D.G., Carroll, A.L., 2006. Surveying mountain pine beetle damage of forests: A review of remote sensing opportunities. For. Ecol. Manage. 221, 27-41.

Xiao, X., Boles, S., Liu, J., Zhuang, D., Liu, M., 2002. Characterization of forest types in Northeastern China: using multi-temporal SPOT-4 VEGETATION sensor data. Remote Sens. Environ. 82, 335-348. 